\title{
OPTIMALIZACE PROCESŮ V AKTIVAČNÍ NÁDRŽI
}

\author{
PROCESS OPTIMALIZATION IN THE ACTIVATION TANK
}

\author{
Ing. et Ing. J edličková Věra; prof. Ing. Hlavínek Petr, CSc., MBA
}

\begin{abstract}
ABSTRAKT
Trendem dnešní doby je nejen zefektivňovat, ale i šetřit náklady. Tento článek je zaměřený na snížení nákladů na provoz čistírny odpadních vod. Čistírenský proces je nepretržitým procesem vyžadujícím pro svou funkci elektrickou energii. Největší množství elektrické energie je spotřebováno v aktivační nádrži, kde je nutné provzdušňování. Zmíněné energetické náklady se v mnoha př́ípadech dají snížit pouhou optimalizací procesů $\mathrm{v}$ aktivační nádrži. $\mathrm{V}$ případě našeho výzkumu se jedná o řízení aerace pomocí pevného nastavení doby nitrifikace a denitrifikace, kdy na základě předchozího pozorování byla snížena doba provzdušnění. Následně bylo prokázáno, že došlo ke třetinovému snížení elektrické energie spotřebované pro aktivační nádrž a to bez jakéhokoliv zhoršení odtokových parametrů.
\end{abstract}

Klíčová slova: Čistírna odpadních vod (ČOV), odpadní voda (OV), nitrifikace a denitrifikace.

\section{ABSTRACT}

Trend today is not only to make more effective but also save costs. This article is aimed at reducing the cost of operating the wastewater treatment plant. Sewage process is a continuous process requiring electricity. The largest amount of electricity is consumed in the aeration tank, where it is necessary aeration. The aforementioned energy costs are in many cases can be reduced simply by optimizing processes in the activation tank. In the case of our research was the control aeration using a hard time setting nitrification and denitrification, which based on a previous observation as reduced aeration. Subsequently it was shown that there was a one-third reduction in the power consumed for the activation tank without any deterioration of the drainage parameters.

Key words: Wastewater treatment plant, wastewater, nitrification and denitrification.

\section{1 ÚVOD}

Čistírny odpadních vod (ČOV) jsou v ekonomicky rozvinutých zemích v podstatě nutností. Jejich úkolem je účinné odstranění znečist'ujících látek škodlivých pro vodní prostředí, jedná se především o látky vyprodukované lidskou činností. Jednou z důležitých znečištujících látek je dusík, který lze z odpadních vod (OV) odstranit pomocí biologické metody, tzv. aktivačního procesu, kde dochází k nitrifikaci a denitrifikaci. K tomuto je procesu však nutné velké množství energie na provzdušnění, které zpravidla představuje nejvyšší procento celkové spotřeby elektrické energie na ČOV. Bylo zjištěno, že velká část stávajících ČOV v České republice nemá efektivní řízení aktivačního procesu. $\mathrm{V}$ důsledku toho dochází ke zbytečnému zvyšování nákladů na provoz celé ČOV, ale i ke zhoršení procesu odstranění znečišt'ujících látek. $V$ dnešní době existují přísná nařízení zaměřující se na kvalitu vyčištěné $\mathrm{OV}$, které je nutné pod hrozbou vysokých sankcí dodržovat. $\mathrm{V}$ případě již zmíněného dusíku se jedná o povolené limity vypouštění $\mathrm{NH}_{4}{ }^{+}$a $\mathrm{N}_{\text {celk, }}$, které jsou společně s dalšími limity uvedeny v Nařízení vlády č. 61/2013. 
$\mathrm{Na}$ českém trhu je možné nalézt několik variant pro odstranění dusíku na ČOV, nejčastěji se však vyskytuje oběhová aktivace, která je současně i jednou z nejstarších metod. V současnosti se ustaluje jejich podoba jako nízkozatížených systémů s dlouho dobou zdržení a s vysokým stářím kalu. Pro odstraňování dusíku jak již bylo výše zmíněno, je nutná dodávka kyslíku, která je zajištěna tak, aby byly tvořeny zóny s rozdílnou koncentrací rozpuštěného kyslíku a došlo k vytvoření optimálních podmínek pro simultánní nitrifikaci a denitrifikaci.

\section{MOŽNOSTI ŘíZENÍ PROCESŮ V AKTIVAČNÍ NÁDRŽI}

Nezbytnou součástí ČOV je aktivační nádrž, kde dochází k biologickému aktivačnímu procesu, tedy procesu nitrifikace a denitrifikace, který z největší části přispívá k odstranění dusíku z odpadních vod. Nitrifikace je autotrofní anaerobní proces oxidace amoniaku na dusičnany s dusitany jako meziproduktem $\left(\mathrm{NH}_{4}{ }^{+} \rightarrow \mathrm{NO}_{2}{ }^{-} \rightarrow \mathrm{NO}_{3}\right)$. Následuje heterotrofní anoxický proces denitrifikace, $\mathrm{kdy}$ dojde k přeměně dusitanů na elementární dusík často s několika meziprodukty $\mathrm{NO}_{3}{ }^{-} \rightarrow \mathrm{NO}_{2}{ }^{-} \rightarrow \mathrm{NO} \rightarrow$ $\mathrm{N}_{2} \mathrm{O} \rightarrow \mathrm{N}_{2}$. [4]. Na průběhu aktivačního procesu se podílí celá řada faktorů (koncentrace rozpuštěného kyslíku a oxidu uhličitého, hodnota $\mathrm{pH}$, teplota atd.), je proto nutné věnovat pozornost optimalizaci tohoto procesu v závislosti na aktuálních podmínkách.

\subsection{Pevně nastavená doba nitrifikace a denitrifikace}

Tento způsob řízení je v současnosti stále hojně využívaným systémem. Jak již název napovídá, jedná se o přesně nastavenou dobu nitrifikace a denitrifikace (především na základě předchozích zkušeností při řízení aktivačních procesů), s následnou úpravou pro konkrétní ČOV. I přes optimalizaci nastavené doby pro danou ČOV nelze touto metodou jakkoliv reagovat na aktuální situaci, tedy aktuální znečištění odpadní vody. S vhodným nastavením délky trvání procesů je však možné dosáhnout kvalitního čištění OV, jak bude dále prezentováno v kapitole 3. Snižení nákladi̊ na řizení aktivační nádrže.

\subsection{Závislost na koncentraci rozpuštěného kyslíku a pH}

Obdobně jako v předchozím případě se jedná o často využívaný způsob řízení, v současnosti nejčastěji využívaný. Jedná se o manuální nastavení pevné hodnoty koncentrace rozpuštěného kyslíku a rozmezí pH. Obecně byla pro odstranění dusitanů zjištěna optimální koncentrace rozpuštěného kyslíku 2,7-5,7 mg/l a optimální pH 6,45-7,85. [2] Vždy je ovšem potřeba ke každé čistírně přistupovat individuálně a hodnoty přizpůsobit konkrétní odpadní vodě. Ne vždy je však dané nastavení dostatečně efektivní a to především v kombinaci s jednobodovým měřením koncentrací v nádrži.

\subsection{Matematický vztah v závislosti na koncentraci amoniakálního dusíku}

Pro tento systém je typická kaskáda regulátorů, kdy je jedním regulátorem stanovena hodnota koncentrace rozpuštěného kyslíku, zatímco druhý regulátor stanovuje veličinu nutnou $\mathrm{k}$ dosažení žádané hodnoty, kterou jsou otáčky dmychadla, případně otevření regulační klapky. Je možné využití PID regulátoru pro stanovení hodnoty koncentrace rozpuštěného kyslíku. Pro regulátor bývá využívána hodnota koncentrace amoniakálního dusíku na odtoku i průměrná koncentrace rozpuštěného kyslíku. Na ČOV v Uppsale je efektivní konstantní nastavení požadovaných hodnot koncentrací rozpuštěného kyslíku 3,5 mg/l a $\mathrm{N}_{\text {amon }} 5 \mathrm{mg} / \mathrm{l}$. [1] 


\subsection{Závislost na koncentraci amoniakálního dusíku}

Možností pro zlepšení odstranění dusíku a šetření nákladů na energie může být také nastavení nitrifikace a denitrifikace na základě měření koncentrace amoniakálního dusíku $\left(\mathrm{N}^{-} \mathrm{NH}_{4}{ }^{+}\right)$. Rízení je prováděno nastavením frekvence motorů dmychadel na základě koncentrace amoniakálního dusíku a to nejlépe na konci aerační zóny. Řízení je zpravidla na základě PID regulátoru s nastavenou koncentrací $\mathrm{N}^{-\mathrm{NH}_{4}}{ }^{+}$na hodnotu $8,5 \mathrm{mg} / \mathrm{l} \mathrm{s}$ tím, že v létě je možné zvýšení na 9,5 mg/l (na ČOV Praha). Při tomto způsobu řízení je nutné nastavit regulátor tak, aby měl delší odezvu, která odpovídá reakční době nitrifikanti̊, tedy cca 1-1,5 hodiny. [3] Je nutné mít na paměti, že výše zmíněná hodnota je závislá na mnoha parametrech, proto není možné ji striktně použít na všech ČOV.

\subsection{Závislost na amoniakálním dusíku a dusičnanech}

Jedná se o velmi přesnou a efektivní metodu při odstranění dusíku, protože je schopna rychle reagovat na aktuální koncentrace $\mathrm{v}$ odpadní vodě. Jedná se o řízení procesů nitrifikace a denitrifikace v závislosti na koncentraci amoniakálního $\left(\mathrm{N}^{\left.-\mathrm{NH}_{4}\right)}\right.$ a dusičnanového $\left(\mathrm{N}^{-} \mathrm{NO}_{3}\right)$ dusíku s jejich vzájemnou vazbou. Pro možnost využití tohoto systému je nutné v aktivační nádrži instalovat dvě, lépe však tři online sondy indikující aktuální koncentraci $\mathrm{N}-\mathrm{NH}_{4}$ a N-NO $\mathrm{N}_{3}$, optimálně i rozpuštěného kyslíku, jako pojistku pro případ poruchy.

První etapou aktivačního procesu je proces nitrifikace, který je zahájen sepnutím aeračního zařízení v závislosti na koncentraci dusičnanového dusíku $\mathrm{N}-\mathrm{NO}_{3}$ a zároveň při dodržení podmínky maximální koncentrace amoniakálního dusíku N-NH . Proces nitrifikace je pak ukončen na základě dosažení dané koncentrace amoniakálního dusíku. Následuje druhá fáze a to denitrifikace, která nastane po vypnutí aeračního zařízení, prričemž v této fázi je hodnota $\mathrm{N}-\mathrm{NO}_{3}$ pouze hodnotou informativní.

\section{SNIIZZENÍ NÁKLADU゚ NA ŘíZENÍ AKTIVAČNÍ NÁDRŽE}

Při čištění odpadních vod je nezbytná dodávka elektrické energie pro jednotlivé procesy čištění. Největší podíl na spotřebě elektrické energie má na svědomí aktivační nádrž. Jak již bylo výše popsáno, pro zajištění aktivačního procesu je nutné provzdušňování aktivační nádrže. Vzhledem k neustále se zvyšujícím cenám energií je žádoucí snížení potřebných nákladů na provoz ČOV. Proto jsme se zaměřili na konkrétní ČOV v obci Mikulov navržené pro $25000 \mathrm{EO}$, jejíž součástí jsou dvě oběhové aktivační nádrže, které jsou řízeny pomocí nastavení pevné doby nitrifikace a denitrifikace. Konkrétně se jedná o následující nastavení: doba nitrifikace 60 min., následuje 10 min. ustálení a poslední nezbytnou fází je 80 min. denitrifikace, jeden cyklus tedy trvá 150 minut. Během nitrifikace přerušovaně docházelo provzdušňování a to v celkové délce $30 \mathrm{~min}$. Při tomto provozu činí spotřeba elektrické energii v aktivační nádrži celých $45 \%$ z celkové spotřeby na čistírenský provoz. Průměrná spotřeba na jednotlivé procesy v červenci 2015 je znázorněna na následujícím grafu Obr. 1 (vlevo). Na úvod je rovněž nutné zmínit, že tato ČOV splňuje veškerá nařízení pro vypouštění odpadních vod. 

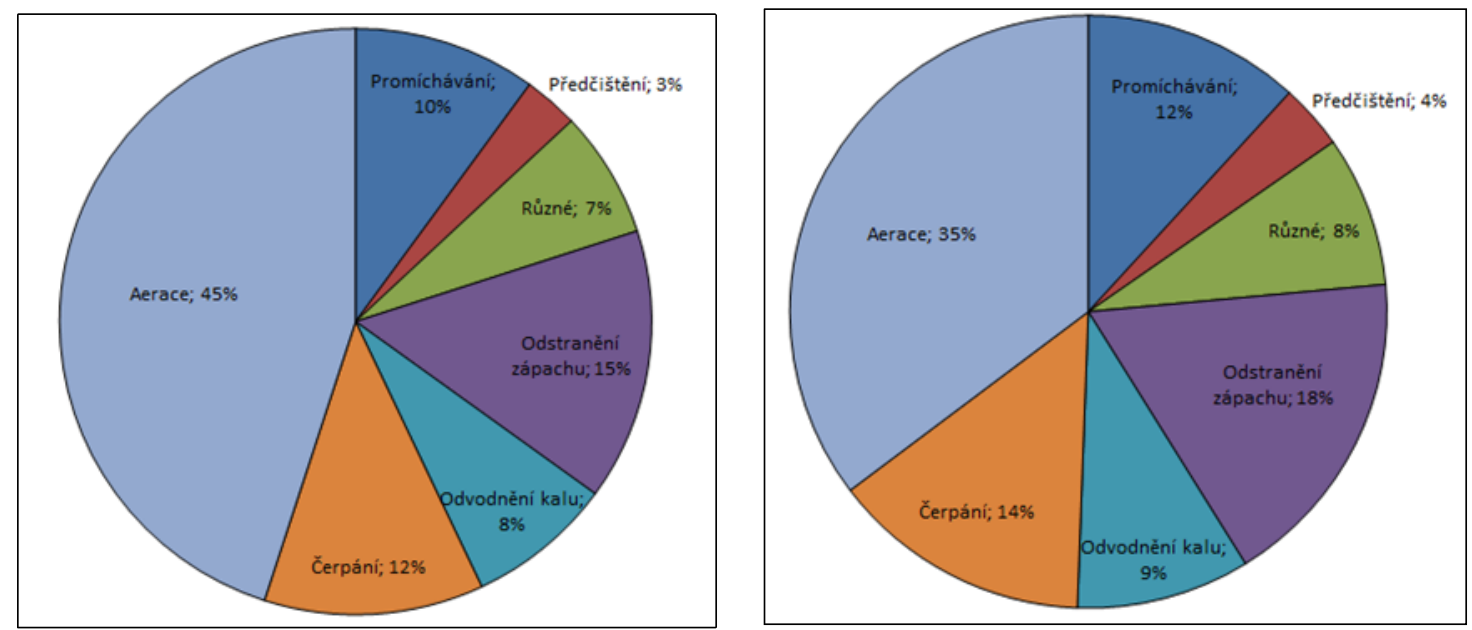

Obr. 1 Procentuální rozdělení spotřeby elektrické energie na čistírně odpadních vod Mikulov, pưvodní nastavení aerace (vlevo), snížená doba aerace (vpravo)

Na ČOV Mikulov není problém s dodržováním povolených limitů pro vypouštění odpadních vod, proto jsme se zaměřili na možnost snížení nákladů, konktrétně tedy na provoz aktivační nádrže. Ke stávající kyslíkové sondě v aktivační nádrži byly instalovány dvě sondy, které online zaznamenávají hodnoty amoniakálního dusíku a dusičnanů. Po dobu několika měsíců byly pozorovány měřené parametry, aby bylo možné provést úpravu nastavení doby nitrifikace a denitrifikace. $\mathrm{Z}$ prováděného měření $\mathrm{N}-\mathrm{NH}_{4}{ }^{+}$a N-NO $\mathrm{N}_{3} \mathrm{v}$ období od května do července se ukázalo, že dochází ke značnému kolísání koncentrací v aktivační nádrži, často i mimo povolené limity což bylo způsobeno vysokým bodovým zatížením (např. vyvážení fekálních vozů), ale i velmi vysokými teplotami v téměř bezdeštném období. V měsíci srpnu proběhlo plánované čištění aktivačních nádrží, přičemž po jejím opětovném zaběhnutí byl nastaven nový režim řízení. Konkrétně došlo ke změně času aerace, což znamená dobu nitrifikace 40 min., ustálení 10 min. s následnou denitrifikací v délce 100 min. Cyklus 150 minut byl ponechán, avšak došlo ke třetinovému snížení doby nitrifikace a tím i ke snížení požadavku na provzdušnění.

Změna cyklu byla změnou velmi pozitivní, došlo ke snížení výkyvů i snížení koncentrací obsahu amoniakálního dusíku $\left(\mathrm{N}^{-} \mathrm{NH}_{4}{ }^{+}\right)$i dusičnanů $\left(\mathrm{N}^{-} \mathrm{NO}_{3}\right)$. Tuto pozitivní změnu nelze přičítat pouze změně doby provzdušňování, ale jistě nese svůj velký podíl i počasí, kvalita vody, vyčištění nádrží a případné další. Velmi pozitivním výsledkem však je, že se po snížení doby aerace ušetřily náklady na spotřebu elektrické energii a nikterak se nezhoršila kvalita vyčištěné odpadní vody, ba naopak oproti přechozímu měření jsou hodnoty koncentrací $\mathrm{N}_{-} \mathrm{NH}_{4}{ }^{+}$a $\mathrm{N}-\mathrm{NO}_{3}$ nižší a kolísání je udržováno v nízkém rozmezí. Změna procentuálního rozdělení celkových nákladů na spotřebu energické energie je názorná na Obr. 1, kdy došlo ke třetinovému snížení nákladů za aeraci, neboli k celkové úspoře za spotřebu energií. Na grafu viz Obr. 2 můžeme názorně vidět hodnoty koncentrací ze sond umístěných v aktivační nádrži v průběhu jednoho dne, hodnoty jsou v jednotlivých dnech samožrejmě rozdílné, avšak s obdobným charakterem i hodnotami. 


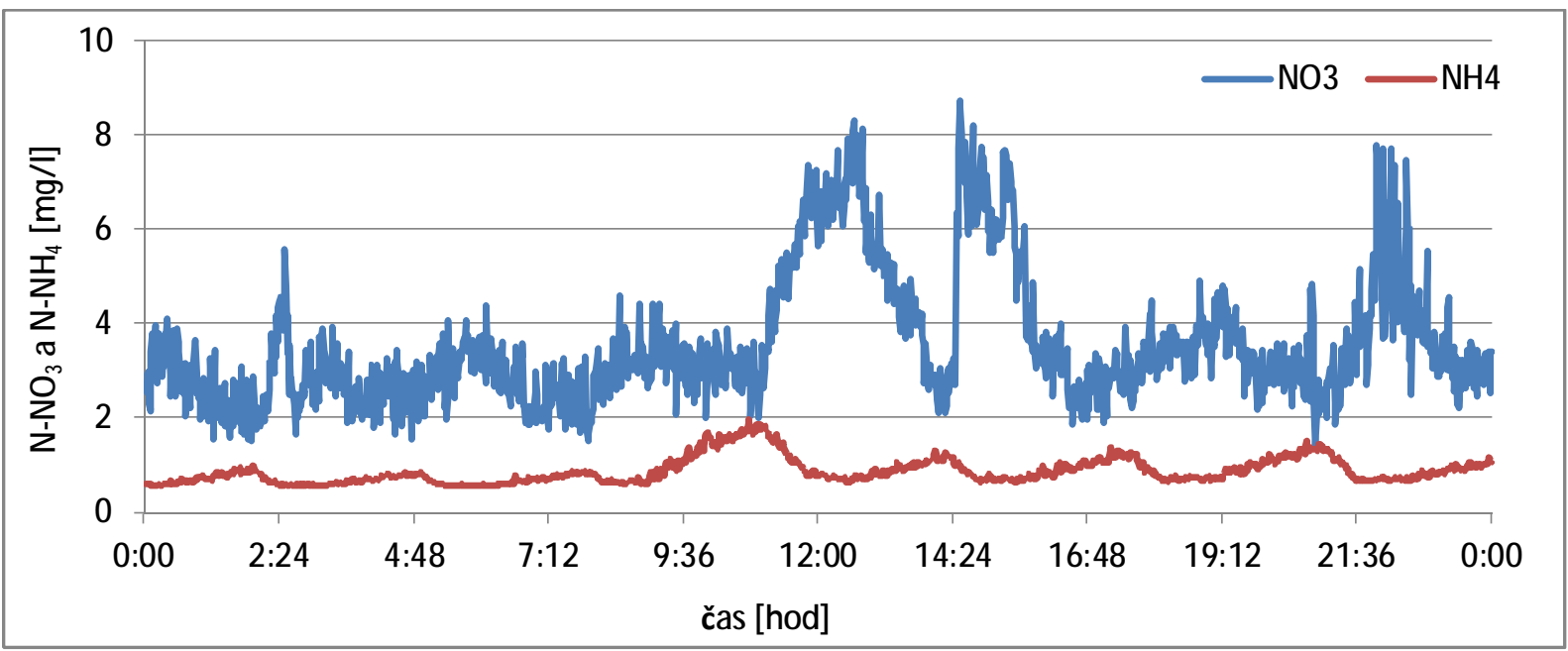

Obr. 2 Ukázka koncentrace amoniakálního dusíku $\left(\mathrm{N}-\mathrm{NH}_{4}{ }^{+}\right)$a dusičnanů $\left(\mathrm{N}-\mathrm{NO}_{3}\right)$ v aktivační nádrži za jeden den, konkrétně dne 22.10. 2015

V následující tabulce pro ucelení informací o kvalitě vody přikládám výsledky rozborů vyčištěné odpadní vody opět ze dne 22. 10. 2015 a to v podobě směsného 24 hodinového vzorku (tytu "b"). Můžeme zde pozorovat zcela vyhovující parametry vody na odtoku.

\begin{tabular}{|c|c|c|c|}
\hline Datum & \multicolumn{2}{|c|}{ 22. 10.2015 } & \\
\hline Průtok & \multicolumn{2}{|c|}{1974} & $\mathrm{~m}^{3}$ \\
\hline \hline & Prítok & Odtok & Jednotky \\
\hline $\mathrm{pH}$ & 7.6 & 7.40 & $\mathrm{mg} / \mathrm{l}$ \\
\hline $\mathrm{CHSK}$ & 542 & 26 & $\mathrm{mg} / \mathrm{l}$ \\
\hline $\mathrm{BSK} 5$ & 161 & 2.7 & $\mathrm{mg} / \mathrm{l}$ \\
\hline $\mathrm{NL}_{\mathrm{c}}$ & 312 & 4 & $\mathrm{mg} / \mathrm{l}$ \\
\hline $\mathrm{N}^{-\mathrm{NO}_{2}}$ & 0.315 & 0.01 & $\mathrm{mg} / \mathrm{l}$ \\
\hline $\mathrm{N}-\mathrm{NO}_{3}$ & 1.11 & 0.54 & $\mathrm{mg} / \mathrm{l}$ \\
\hline $\mathrm{N}-\mathrm{NH}_{4}$ & 26.9 & $<0,28$ & $\mathrm{mg} / \mathrm{l}$ \\
\hline $\mathrm{N}-$-anorg & 28.30 & 0.708 & $\mathrm{mg} / \mathrm{l}$ \\
\hline $\mathrm{P}_{\mathrm{c}}$ & 6.15 & 0.28 & $\mathrm{mg} / \mathrm{l}$ \\
\hline
\end{tabular}

Tab. 1 výsledky rozborů vyčištěné odpadní vody

\section{ZÁVĚR}

Možnost úspory energie v aktivační nádrži se ukázala jako velice úspěšná a to i při zachování stávajícího procesu řízení. Pouhou úpravou pevné doby nitrifikace a denitrifikace, tedy úpravou doby provzdušnění, je možné optimalizovat proces čištění odpadních vod. Tímto dojde ke snížení nákladů elektrické energie pro provoz v aktivační nádrži, což se pozitivně projeví i na celkových nákladech nutných pro provoz čistírny odpadních vod. Existuje více možností, jak snížit spotřebu energií na čistírenský proces, proto se budoucnu zaměříme na optimalizaci řízení procesu nitrifikace a denitrifikace změnou způsobu řízení. Avšak pozitivním zjištěním je, že zle snížit provozní náklady ČOV i bez vynaložení vysokých pořizovacích nákladů. 


\section{Poděkování}

Článek byl vytvořen v rámci řešení projektu č. LO1408 "AdMaS UP - Pokročilé stavební materiály, konstrukce a technologie" podporovaného Ministerstvem školství, mládeže a tělovýchovy v rámci účelové podpory programu „Národní program udržitelnosti I" a projektu FAST-J-15-2745 podporovaného v rámci juniorského projektu specifického výzkumu.

Chtěla bych poděkovat panu Otovi Dubinovi, mistru ČOV Mikulov za ochotu a pomoc při sběru dat.

\section{Použitá literatura}

[1] OLSSON, G. \& NEWELL, B. Watewater Treatment Systems Modelling, Diagnosis and Control, London, IWA Publishing, 1999, 1371-1377s.

[2] RUIZ, G., JEISON, D., CHAMY R. Nitrification with high nitrite accumulation for the treatment of watewater with high ammonia concentration. Water research, 2003.

[3] TALLEC, G., GARNIER, J., GOUSAILLES, M., Nitrogen removal in a watewater treatment plant throught biofilters: nitrous oxide emission during nitrification and denitrifiation. Springer-Verlag 2006, Bioprosess Biosyst Eng (2006) str. 232-333, DOI 10.1007/s00449-0060081-0.

[4] TODT, V., HRUBÝ, T. \& MAREŠ, J., Specifické dávkování chemikálií a ř́zení dodávky vzduchu dle koncentrace $\mathrm{N}-\mathrm{NH}_{4}^{+}$na ÚC̆OV Prha. Odpadní vody - Veolia Voda, Plzeň, 2012. 